\title{
Ectoparasites as numerical dominant species in parasite community of Trachelyopterus striatulus (Siluriformes: Auchenipteridae) from Guandu River, southeastern Brazil
}

\author{
Mesquita, RLB. ${ }^{a}$, Azevedo, RK. ${ }^{a}$, Abdallah, VD. ${ }^{a}$ and Luque, JL. ${ }^{b *}$ \\ ${ }^{a}$ Curso de Pós-Graduação em Ciências Veterinárias, \\ Universidade Federal Rural do Rio de Janeiro - UFRRJ, Seropédica, RJ, Brazil \\ ${ }^{\text {b}}$ Departamento de Parasitologia Animal, Universidade Federal Rural do Rio de Janeiro - UFRRJ, \\ CP 74.508, CEP 23851-970, Seropédica, RJ, Brazil \\ *e-mail: jlluque@ufrrj.br
}

Received June 6, 2010 - Accepted August 19, 2010 - Distributed 31 August, 2011

(With 1 figure)

\begin{abstract}
Sixty specimens of singing catfish Trachelyopterus striatulus (Steindachner, 1877) (Siluriformes: Auchenipteridae) collected from Guandu River ( $22^{\circ} 48^{\prime} 32^{\prime} \mathrm{S}$ and $43^{\circ} 37^{\prime} 35^{\prime} \mathrm{W}$ ), in the state of Rio de Janeiro, Brazil from October 2006 to March 2009, were necropsied to study their parasites. From the 60 specimens of T. striatulus examined 57 were parasitised by at least one parasite species. The majority of the parasite specimens collected were monogeneans followed by Nematoda, Digenea and Hirudinea. Cosmetocleithrum sp. was the numerically predominant species with highest prevalence and abundance. The parasites of $T$. striatulus showed the typical pattern of aggregated distribution. No parasite species showed significant correlation between the body total length of the host and their abundance. The mean parasite species richness was not correlated with the host's total body length and sex. Values of the Brillouin index of diversity had a mean of $\mathrm{H}=0.083 \pm 0.136$.
\end{abstract}

Keywords: parasite ecology, fish parasites, Trachelyopterus striatulus, Guandu River, Brazil.

Ectoparasitos como espécies numericamente dominantes na comunidade parasitária de Trachelyopterus striatulus (Siluriformes: Auchenipteridae) do rio Guandu, Sudeste do Brasil

\section{Resumo}

Entre outubro de 2006 a março de 2009 foram necropsiados 60 espécimes de cumbaca, Trachelyopterus striatulus

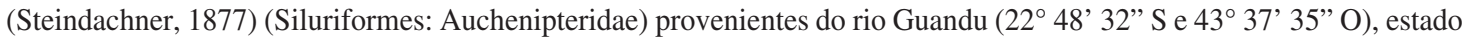
do Rio de Janeiro, Brasil para estudo de suas comunidades parasitárias. Dos 60 espécimes de peixes examinados, 57 estavam parasitados por pelo menos uma espécie de metazoário parasito. Os monogenéticos constituíram a maioria dos espécimes coletados, seguidos de Nematoda, Digenea e Hirudinea. Cosmetocleithrum sp. foi a espécie numericamente predominante, com maiores valores de prevalência e abundância. Os parasitos de T. striatulus apresentaram um típico padrão de distribuição agregado. Nenhuma espécie de parasito apresentou correlação significativa entre o comprimento total do hospedeiro e sua abundância. A avaliação do efeito do sexo do hospedeiro na abundância parasitária não apresentou resultados significativos. A riqueza de espécies de parasitos não apresentou correlação com o comprimento total e sexo dos hospedeiros. As infracomunidades parasitárias tiveram uma média para o índice de diversidade de Brillouin de $\mathrm{H}=0.083 \pm 0.136$.

Palavras-chave: ecologia parasitária, fish parasites, Trachelyopterus striatulus, rio Guandu, Brasil. 


\section{Introduction}

The singing catfish Trachelyopterus striatulus (Steindachner, 1877) (Auchenipteridae) is a demersal, endemic to South America and widely distributed in coastal rivers from southeastern Brazil (Bizerril and Primo, 2001). According to Froese and Pauly (2009), four synonyms are known: Auchenipterus striatulus, Parauchenipterus striatulus (Steindachner, 1877), Trachycorystes striatulus (Steindachner, 1877) and Trachycorystes striatus (Steindachner, 1877). The diet of T. striatulus consists of items from both terrestrial environment (Coleoptera, Hymenoptera and Hemiptera) and from the aquatic environment: (diatoms, rotifers, mollusks and crustaceans) with a clear tendency to insectivorous, which suggests greatly diversified omnivorous food habits that could be highly adaptable to the environment (Dias et al., 2005).

The Guandu River supplies water to $90 \%$ of the population of Rio de Janeiro city and although it is a very impacted environment (Bizerril and Primo, 2001), it maintains an important level of biodiversity of fishes, and consequently, fish parasites (Abdallah et al., 2006; Azevedo et al., 2007). Only three studies on the parasites of T. striatulus from Brazil were published: Kritsky et al. (1995) observed a species of Scleroductus from Guandu river; Moreira et al. (2000) described a new species of Cucullanus from State of Minas Gerais, and Paraguassú and Luque (2007) performed preliminary studies on quantitative aspects of the parasites of $T$. striatulus from Lajes reservoir. Other quantitative studies on parasites of auchenipterid fishes from Brazil is that of Tavernari et al. (2009) who studied Auchenipterus osteomystax Miranda Ribeiro, 1918 from two different environments, Rosana's reservoir and the upper Paraná river floodplain. Here, we analysed the metazoan parasite community of $T$. striatulus from the Guandu River, in the state of Rio de Janeiro, at the component and infracommunity levels.

\section{Materials and Methods}

Sixty specimens of T. striatulus from October 2006 to March 2009 were collected from the Guandu river $\left(22^{\circ} 48^{\prime} 32^{\prime \prime} \mathrm{S}\right.$ and $\left.43^{\circ} 37^{\prime} 35^{\prime \prime} \mathrm{W}\right)$, in the state of Rio de Janeiro, Brazil. The fishes were identified according to Britski et al. (1999) and measured $19.2 \pm 1.4(16.7-24) \mathrm{cm}$ in total length. The average total length of male was $19.2 \pm 1.2 \mathrm{~cm}(\mathrm{n}=32)$ and female was $19.2 \pm 1.6 \mathrm{~cm}$ $(\mathrm{n}=28)$. Parasite prevalence, intensity, and abundance were calculated according to Bush et al. (1997). The variance to mean ratio of parasite abundance (index of dispersion) was used to determine spatial distribution patterns and tested by the $d$ statistical index (Ludwig and Reynolds, 1988). The Berger-Parker dominance index was calculated (Magurran, 1988); and the frequency of dominance of each parasite species was calculated according to Rohde et al. (1995). Spearman's rank correlation coefficient $r s$ was calculated to determine possible correlations between the host's total body length and abundance of parasites (Zar, 1999). The possible influence of host sex on abundance of parasites was tested using the $Z$ normal approximation to the MannWhitney test. The analysis included only parasite species with prevalence greater than $10 \%$ (Bush et al., 1990). Finally, the Brillouin's diversity index (log 10 based) was calculated (Zar, 1999); the probable variation of parasite species diversity in relation to host sex (Mann-Whitney test) and to host total length (Spearman's rank correlation coefficient) was tested. Ecological terminology follows Bush et al. (1997). The statistical significance level was evaluated at $\mathrm{p} \leq 0.05$. Voucher specimens of helminths were deposited in the Coleção Helmintológica do Instituto de Biociências, Botucatu, (CHIBB), in the state of São Paulo, Brazil.

\section{Results}

\subsection{Component community}

Ten species of metazoan parasites were collected (Table 1). The majority of the parasites specimens collected were monogeneans, followed by digeneans, nematodes and hirudineans. The monogenean Cosmetocleithrum sp. was the predominant species, with 2402 specimens collected (98\% of all parasites); and showed the highest values of frequency of dominance $(96.6 \%)$. No parasite showed a significant correlation between the hosts' total length and their abundance. None of the parasites showed a difference in their abundance in relation to sex of the host. The length of males and females was not significantly different by the $t$-Student test $(\mathrm{t}=0.43 ; \mathrm{p}=0.67)$.

\subsection{Infracommunities}

From the 60 specimens of $T$. striatulus examined, 57 were parasitised by at least one parasite species. A total of 2434 individual parasites were collected, with mean of 40.6 parasites/fish. Cosmetocleithrum sp. and the digenean Clinostomum detruncatum showed the typical pattern of aggregated distribution, with (ID $=6.83 ; \mathrm{d}=57.35)$ and (ID $=2.34 ; d=5.80$ ) respectively. Relationships between the total parasite abundance and the host's total body length ( $r s=0.108, p=0.430$ ) of fish were not observed. Relationships between the total parasite abundance and the host's sex $(\mathrm{Zc}=-0.329, \mathrm{p}=0.741)$ of fish were not observed. The mean parasite species richness $1.5 \pm 0.75$ (0-3), was not correlated with the host's total body length ( $\mathrm{rs}=0.515, \mathrm{p}=0.608)$ and with the host's sex $(\mathrm{Zc}=-0.311$, $\mathrm{p}=0.755)$. Three hosts were not infected and 31,19 and 7 had infections with 1, 2 and 3 parasite species, respectively (Figure 1). The parasite infracommunities had a mean diversity of $\mathrm{H}=0.083 \pm 0.136$ and highest value of diversity of 0.449 . No significant relationship was detected between the parasite species diversity and the host sex $(\mathrm{Zc}=-0.192, \mathrm{p}=0.848)$ and the host total length ( $\mathrm{rs}=0.149, \mathrm{p}=0.276$ ). The mean of Berger-Parker index was $0.914 \pm 0.001$. 
Table 1. Prevalence, mean abundance, mean intensity and site of infection of the metazoan parasites of Trachelyopterus striatulus from Guandu river in the State of Rio de Janeiro, Brazil.

\begin{tabular}{|c|c|c|c|c|}
\hline Parasites & $\begin{array}{c}\text { Prevalence } \\
(\%)\end{array}$ & $\begin{array}{c}\text { Mean } \\
\text { abundance }\end{array}$ & $\begin{array}{c}\text { Mean } \\
\text { intensity }\end{array}$ & $\begin{array}{c}\text { Site of } \\
\text { infection }\end{array}$ \\
\hline \multicolumn{5}{|l|}{ Digenea } \\
\hline $\begin{array}{l}\text { Clinostomum detruncatum } \\
\text { (metacercariae) } \\
\text { CHIBB No 048L }\end{array}$ & 11.7 & $0.2 \pm 1.3$ & $1.7 \pm 1.9$ & Muscle \\
\hline $\begin{array}{l}\text { Austrodiplostomum compactum } \\
\text { (metacercariae) } \\
\text { CHIBB No 045L }\end{array}$ & 1.7 & $0.02 \pm 0.3$ & $1.0 \pm 0.5$ & Eyes \\
\hline $\begin{array}{l}\text { Posthodiplostomum macrocotyle } \\
\text { (metacercariae) } \\
\text { CHIBB No 005L }\end{array}$ & 3.3 & $0.03 \pm 0.45$ & $1.0 \pm 0.57$ & Stomach \\
\hline Monogenea & & & & Gills \\
\hline Cosmetocleithrum sp. & 95.0 & $40.03 \pm 4.5$ & $42.14 \pm 4.8$ & Gills \\
\hline \multicolumn{5}{|l|}{ Nematoda } \\
\hline $\begin{array}{l}\text { Procamallanus (Procamallanus) } \\
\text { peraccuratus } \\
\text { CHIBB No } 5006\end{array}$ & 6.7 & $0.07 \pm 0.38$ & $1.0 \pm 0.6$ & Mesenteries \\
\hline $\begin{array}{l}\text { Cucullanus sp. } \\
\text { CHIBB No } 4997\end{array}$ & 1.7 & $0.04 \pm 0.3$ & $2.0 \pm 1.1$ & Mesenteries \\
\hline $\begin{array}{l}\text { Paracapillaria piscicola } \\
\text { CHIBB No } 4998\end{array}$ & 3.4 & $0.03 \pm 0.2$ & $1.0 \pm 0.9$ & Mesenteries \\
\hline $\begin{array}{l}\text { Contracaecum sp. (larval) } \\
\text { CHIBB No } 5011\end{array}$ & 1.7 & $0.02 \pm 0.1$ & $1.0 \pm 0.6$ & Liver \\
\hline $\begin{array}{l}\text { Hysterothylacium sp. (larval) } \\
\text { CHIBB No } 5013\end{array}$ & 1.7 & $0.07 \pm 0.28$ & $4.0 \pm 2.8$ & Mesenteries \\
\hline \multicolumn{5}{|l|}{ Hirudinea } \\
\hline $\begin{array}{l}\text { Helobdella sp. } \\
\text { CHIBB No 022L }\end{array}$ & 1.7 & $0.02 \pm 0.4$ & $1.0 \pm 1.2$ & Gills \\
\hline
\end{tabular}

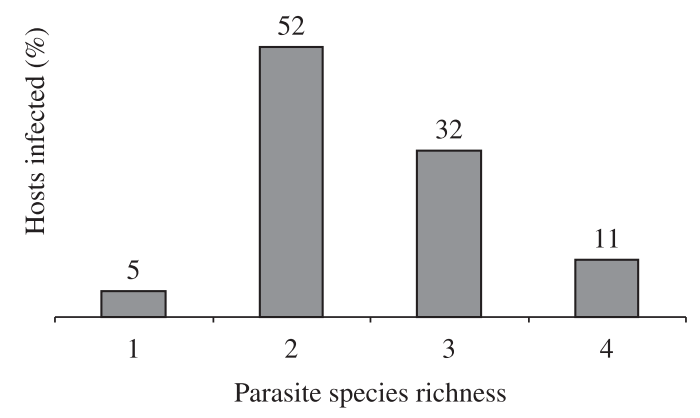

Figure 1. Distribution of species richness in the parasite infracommunities of Trachelyopterus striatulus from Guandu River in the State of Rio de Janeiro, Brazil.

\section{Discussion}

Parasite communities of the T. striatulus studied are characterised by the presence of species with low prevalence and abundance, and by low values of parasite species richness in the component communities. Trachelyopterus striatulus showed a parasite community with dominance of ectoparasites. The monogenean Cosmetocleithrum sp. was the most prevalent and abundant species. With respect to the high abundance values recorded for ectoparasite species, these might be related to the preference of T. striatulus by lentic environment, which according to Dogiel (1961), might facilitate transmission of ectoparasites with a direct life-cycle. Monogeneans could provoke an excessive production of mucus on the gill filaments, decreasing the fish respiratory capacity. Thus, fish that seem to tolerate heavy infestations may die suddenly when the oxygen content of the water falls slightly (Boeger and Viana, 2006).

The presence of larval stages of digeneans and nematodes suggests that $T$. striatulus might occupy an intermediate trophic level at the freshwater food web. This situation would be related with the feeding behaviour of T. striatulus, since two of the main food items of this fish are mollusks and crustaceans, which are potential intermediate hosts for digeneans and nematodes respectively, although the prevalence, intensity and abundance of infection were low. In work carried out by Martins et al. (2002) and Santos et al. (2002) with Plagioscion squamosissimus Heckel, 1840 and Cichla ocellaris Bloch and Schneider, 1801, both piscivorous fish, the prevalence, intensity and abundance of infection by metacercariae of Austrodiplostomum 
compactum were much higher than those observed in this study. In the study by Martins et al. (2005), Hoplias malabaricus (Bloch, 1794) and Hoplerythrinus unitaeniatus (Spix and Agassiz, 1829), essentially ichthyophagous in the adult stage, the prevalence and intensity of infection by larvae of Contracaecum were much higher than those observed in this study.

Another pattern was detected in the parasite community of T. striatulus: the total parasite abundance and the parasite richness were not correlated with size and sex of the host. This absence of correlation with the size suggests homogeneity of diet components or feeding behaviour between $T$. striatulus diverse age classes. It is a pattern previously found in other fishes from Guandu river (Abdallah et al., 2004; Azevedo et al., 2006, 2007; Santos et al., 2007). The lack of correlation with the sex of hosts might be attributed to similarity in ecological relationships (behaviour, habitat and diet) of males and females. Moreover, the lengths of male and female not were significantly different; thus, equalities between female and male infection levels were found. Some fishes from Guandu River previously studied, presented absence of correlation with the sex of host (Abdallah et al., 2005; Azevedo et al., 2006; Santos et al., 2007). According to Poulin (1996), the host sex influence on parasite prevalence and abundance is a topic hardly touched upon in community analysis discussions, and it is necessary to conduct further experiments which show the influence of other factors mainly on fish physiology and behaviour.

Paraguassú and Luque (2007) recorded only Dactylogyridae gen. sp. from a sample of 34 specimens of T. striatulus from Lajes reservoir, Rio de Janeiro, with prevalence values lower than those determined in the present work. With exception of Cucullanus sp., the other parasites have been recorded for the first time in T. striatulus. Also, Clinostomum detruncatum, $P$. (P.) peraccuratus and $P$. piscicola, are new records in fishes of the Guandu river, expanding the geographic distribution of these parasites.

Acknowledgements - Raquel L. B. Mesquita was supported by a student fellowship from CNPq (Conselho Nacional de Pesquisa e Desenvolvimento Tecnológico, Brazil); Rodney K. Azevedo was supported by student fellowships from FAPERJ (Fundação de Amparo à Pesquisa do Estado do Rio de Janeiro, Brazil); Vanessa D. Abdallah was supported by a student fellowship from CNPq and José L. Luque was supported by a Research fellowship from $\mathrm{CNPq}$ and by a grant from FAPERJ.

\section{References}

ABDALLAH, VD., AZEVEDO, RK. and LUQUE, JL., 2004. Metazoários Parasitos dos lambaris Astyanax bimaculatus (Linnaeus, 1758), A. parahybae Eigenmann, 1908 e Oligosarcus hepsetus (Cuvier, 1829) (Osteichthyes: Characidae), do Rio Guandu, Estado do Rio de Janeiro, Brasil. Revista Brasileira de Parasitologia Veterinária, vol. 13, n. 2, p. 57-63.

-, 2005. Metazoários parasitos do sairú Cyphocharax gilbert (Quoy e Gaimard, 1824) (Osteichthyes: Curimatidae), do Rio Guandu, Estado do Rio de Janeiro, Brasil. Revista Brasileira de Parasitologia Veterinária, vol. 14, n. 4, p. 154-159.
-, 2006. Ecologia da comunidade parasitária do tamboatá Hoplosternum littorale (Siluriformes: Callichthyidae) do Rio Guandu, Estado do Rio de Janeiro, Brasil. Acta Scientiarum, vol. 28, n. 4, p. 413-419.

AZEVEDO, RK., ABDALLAH, VD. and LUQUE, JL., 2006. Ecologia da comunidade de metazoários parasitos do acará Geophagus brasiliensis (Perciformes: Cichlidae) do Rio Guandu, Estado do Rio de Janeiro, Brasil. Acta Scientiarum, vol. 28, n. 4, p. 403-411.

-, 2007. Ecologia da comunidade de metazoários parasitos do apaiarí Astronotus ocellatus (Cope, 1872) (Perciformes: Cichlidae) do rio Guandu, estado do Rio de Janeiro, Brasil. Revista Brasileira de Parasitologia Veterinária, vol. 16, n. 1, p. 15-20. PMid:17588317.

BIZERRIL, CRSF. and PRIMO, PBS., 2001. Peixes de águas Interiores do Estado do Rio de Janeiro. Fundação de Estudos do Mar. 417 p.

BOEGER, WA. and VIANNA, RT., 2006. Monogenoidea. In THATCHER, VE. Amazon Fish Parasites. Sofia: Pensoft Publishers. p. 42-116.

BRITSKI, HA., SILIMON, KZS. and LOPES, BS., 1999. Peixes do Pantanal. Manual de identificação. Brasília: Embrapa. 184 p.

BUSH, AO., AHO, JM. and KENNEDY, CR., 1990. Ecological versus phylogenetic determinants of helminth parasite community richness. Evolutionary Ecology, vol. 4, n. 1, p. 1-20.

BUSH, AO., LAFFERTY, KD., LOTZ, JM. and SHOSTAK, AW., 1997. Parasitology meets ecology on its own terms: Margolis et al. revisited. Journal of Parasitology, vol. 83, n. 4, p. 575-583. http://dx.doi.org/10.1007/BF02270711

DIAS, ACML., BRANCO, CWC. and LOPES, VG., 2005. Estudo da dieta natural de peixes no reservatório de Ribeirão das Lajes, Rio de Janeiro, Brasil. Acta Scientiarum, vol. 27, n. 4, p. 355-364.

DOGIEL, VA., 1961. Ecology of the parasites of freshwater fishes. In DOGIEL, V.A., PETRUSHEVSKI, GK. and POLYANSKI, YI. Parasitology of fishes. Leningrad: University Press. p. 1-47.

FROESE, R. and PAULY, D., 2009. FishBase. World Wide Web electronic publication, Version 09/2009. Available from: <www. fishbase.org $>$.

KRITSKY, DC., BOEGER, WA. and POPAZOGLO, F., 1995. Neotropical Monogenoidea. 22. Variation in Scleroductus species (Gyrodactylidae) from Siluriform fishes of Southeastern Brazil. Journal of Helminthological Society of Washington, vol. 62, n. 1 , p. 53-56.

LUDWIG, JA. and REYNOLDS, JF., 1988. Statistical ecology: a primer on methods and computing. New York: Wiley-Interscience Publications.

MAGURRAN, AE., 1988. Ecological diversity and its measurement. New Jersey: Princeton University Press. 192 p.

MARTINS, ML., ONAKA, EM. and FENERICK JR, J., 2005. Larval Contracaecum sp. (Nematoda: Anisakidae) in Hoplias malabaricus and Hoplerythrinus unitaeniatus (Osteichthyes: Erythrinidae) of economic importance in occidental marshlands of Maranhão, Brazil. Veterinary Parasitology, vol. 127, n. 1, p. 51-59. PMid:15619375. http://dx.doi.org/10.1016/j.vetpar.2004.09.026

MARTINS, ML., PAIVA, AMFC., FUJIMOTO, RY., SCHALCH, SHC. and COLOMBANO, NC., 2002. Prevalência, sazonalidade e intensidade de infecção por Diplostomum (Austrodiplostomum) compactum Lutz, 1928 (Digenea, Diplostomidae), em peixes do 
reservatório de Volta Grande, Estado de Minas Gerais, Brasil. Acta Scientiarum, vol. 24, n. 2, p. 469-474.

MOREIRA, NIB., ROCHA, GN. and COSTA, HMA., 2000. A new nematode species (Seuratoidea, Cucullanidae) parasitizing Parauchenipterus striatulus (Steindachner, 1876) (Pisces, Auchenipteridae) in Brazil. Memórias do Instituto Oswaldo Cruz, vol. 95 , n. 1, p. 39-41.

PARAGUASSÚ, AR and LUQUE, JL., 2007. Metazoários parasitos de seis espécies de peixes do reservatório de Lajes, estado do Rio de Janeiro, Brasil. Revista Brasileira de Parasitologia Veterinária, vol. 16, n. 3, p. 121-128. PMid:18078597.

POULIN, R., 1996. Sexual inequalities in helminth infections: a cost of being a male. American Naturalist, vol. 147, n. 2, p. 287 295. http://dx.doi.org/10.1086/285851

ROHDE, K., HAYWARD, C. and HEAP, M., 1995 Aspects of the ecology of metazoan ectoparasites of marine fishes. International Journal for Parasitology, vol. 25, n. 8, p. 945-970. http://dx.doi. org/10.1016/0020-7519(95)00015-T
SANTOS, MD., LEMOS-PITA, SRLC. and BRASIL-SATO, MC., 2007. Fauna de parasitos metazoários de Pimelodus maculatus La Cépède, 1803 (Siluriformes, Pimelodidae) do rio Guandu, Estado do Rio de Janeiro, Brasil. Acta Scientiarum, vol. 29, n. 1, p. 101-107.

SANTOS, RS., PIMENTA, FDA., MARTINS, ML., TAKAHASHI, HK. and MARENGONI, NG. 2002. Metacercárias de Diplostomum (Austrodiplostomum) compactum Lutz, 1928 (Digenea, Diplostomidae) em peixes do rio Paraná, Brasil. Prevalência, sazonalidade e intensidade de infecção. Acta Scientiarum, vol. 24, n. 2 , p. $475-480$.

TAVERNARI, FC., TAKEMOTO, RM., GUIDELLI, GM., LIZAMA, MLAP., LACERDA, ACF. and PAVANELLI, G.C., 2009. Parasites of Auchenipterus osteomystax (Osteichthyes, Auchenipteridae) from two different environments, Rosana's reservoir and upper Paraná river floodplain, Brazil. Acta Scientiarum, vol. 31, n. 1, p. 49-54. http://dx.doi.org/10.4025/actascibiolsci.v31i1.833

ZAR, JH., 1999. Biostatistical Analysis. New Jersey: PrenticeHall, Inc. 663 p. 
